\title{
Status of Red-footed Boobies Sula sula on Little Cayman, British West Indies
}

\author{
FREDERIC J. BURTON, PATRICIA E. BRADLEY, ELIZABETH A. \\ SCHREIBER, GARY A. SCHENK and RICHARD W. BURTON
}

\begin{abstract}
Summary
The island of Little Cayman, in the north-west Caribbean, supports a large breeding colony of Red-footed Boobies Sula sula, within a Ramsar site, the Booby Pond Nature Reserve, protected and managed by the National Trust for the Cayman Islands. Comparison of aerial photographs from 1994 and 1997 shows the colony area unchanged over this time period, occupying 16.5 ha. Area sampling yielded an estimate of 4,839 nesting pairs on Little Cayman in 1997, representing c. 30\% of the entire Caribbean population for this species. Low mortality and excellent condition of chicks indicated a very successful breeding year with good food availability. Aerial photography proved to be an effective tool for determining the colony area but nests visible on these images did not correlate sufficiently well with ground data to be considered a viable basis for population monitoring. The 1997 census will serve as an important baseline, as Little Cayman is on the brink of explosive real estate development which is likely to have a severe impact on the island's natural resources over the next decade.
\end{abstract}

\section{Introduction}

Our knowledge of the status of seabird colonies throughout the entire Caribbean is severely limited, while tourism and development are proceeding almost unchecked as Caribbean countries search for ways to improve their economic status. We do know that many colonies have been extirpated since human colonization (Steadman et al. 1984, Schreiber et al. 1996). The few data available on remaining colonies are fragmentary, incomplete, and mostly out of date (van Halewyn and Norton 1984). The need for surveys and for establishing banding and regular census programs is vital if we are to preserve Caribbean seabirds (ICBP Seabird Specialist Group 1984). The Caribbean harbours $91 \%$ of the population of the Red-footed Booby subspecies Sula sula sula (Schreiber et al. 1996), with Little Cayman long known to support one of its largest breeding colonies (Diamond 1980, van Halewyn and Norton 1984, Clapp 1987).

The Little Cayman colony came under full legal protection in 1993 (Cayman Islands Government 1993) and was designated a Ramsar site in 1994. Partial ownership with full management responsibility was assigned to the National Trust for the Cayman Islands in 1995, when the site became the Booby Pond Nature Reserve. The colony was first described in August 1975 (Diamond 1980) and surveyed in January 1986 (Clapp 1987). The protected area management planning team established by the Trust recommended a new survey of the breed- 


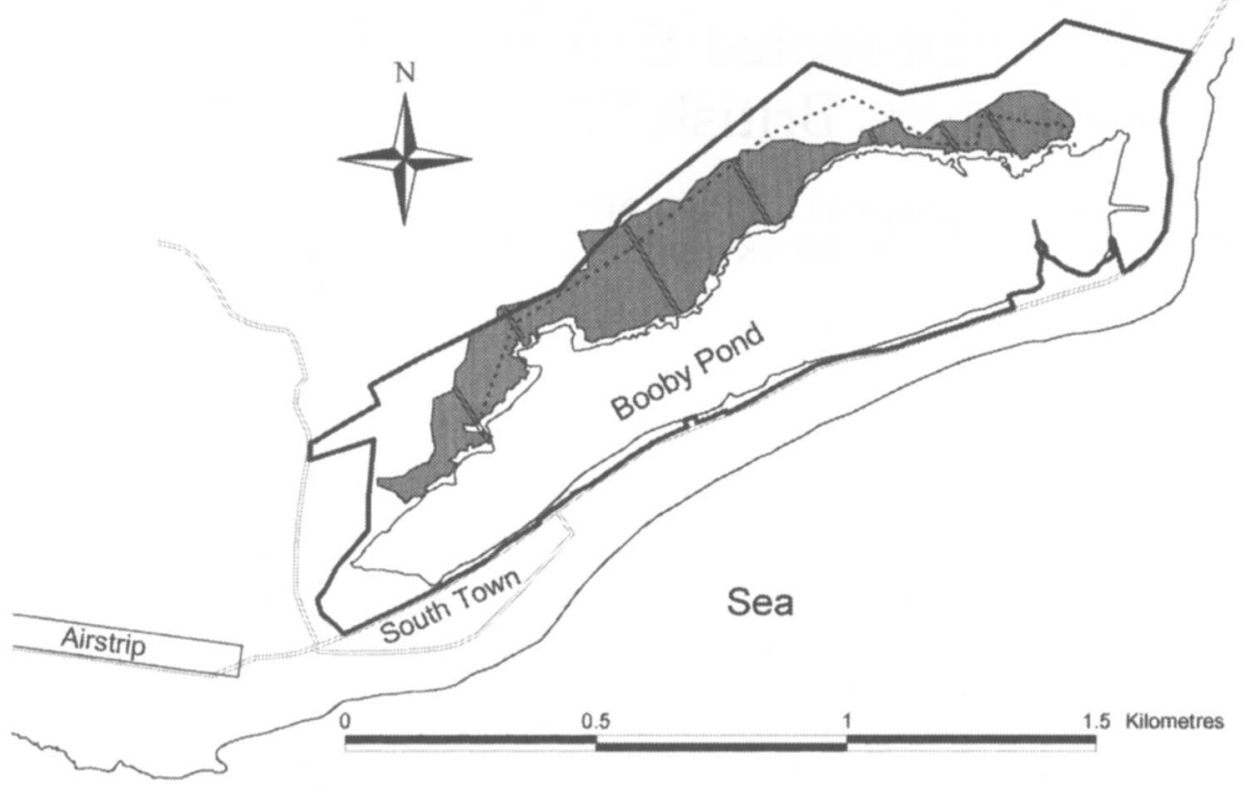

Figure 1. Nesting area on Little Cayman of Red-footed Boobies in 1994 and 1997 (shaded area), compared with 1986 (dotted line, after Clapp 1987). Heavy line is the protected area boundary.

ing Boobies, in order to assess the species's conservation status, the adequacy of the protected area boundary, and attempt to establish a technique and baseline for ongoing monitoring. This survey was carried out in February 1997.

\section{Methods}

The geographic area of the breeding colony in 1994 and 1997 was estimated from aerial photographs. Large format images from March 1994, digitized and ortho-rectified, were combined with digitized land parcel maps using ArcView software. The extent of the colony was clearly visible as a scattering of white pixels on otherwise dark vegetation, probably representing some combination of guano-splashed vegetation, large downy chicks and white morph adults. The boundary of the colony where white pixels abruptly ceased was sufficiently clear to be digitized on screen, allowing a digital estimation for the colony area.

A Turbo Thrush Commander fitted with a bracket for vertical photography using a standard 35-mm camera, was flown to Little Cayman on 11 March 1997. The colony was photographed with a $24-\mathrm{mm}$ lens, in two flight lines spaced at $150 \mathrm{~m}$, at an altitude of $152 \mathrm{~m}$. The photographs were printed and superimposed on a matched scale printout of the digitized map from 1994, allowing direct comparison.

For the ground survey, quadrats were placed along transects (Figure 1), which were located using visible landmarks to match the illustrated position of 6 of the 10 transects laid out and counted by Clapp (1987). An additional seventh transect 
Table 1. Frequency of nest stages of Red-footed Boobies in sample quadrats

\begin{tabular}{lc}
\hline Nest contents: & Frequency \\
\hline Adult on empty new nest & 8 \\
Adult on egg & 47 \\
Adult on small chick & 53 \\
Adult on nest (contents unknown) & 26 \\
Medium chick & 30 \\
Large chick & 142 \\
Prefledge chick & 39 \\
Failed/abandoned/fledged & 2 \\
Total & 347 \\
\hline
\end{tabular}

was established through the heart of the colony. For each transect a rope was pulled through the colony at right angles to the long axis of the pond and the colony, on a compass bearing of $330^{\circ}$. A second rope was spaced at $15 \mathrm{~m}$ from the first. The transects were then divided across into consecutive $15 \mathrm{~m}$ by $15 \mathrm{~m}$ quadrats, from the vegetation line on the northern shore of the pond, through the entire width of the colony until no further nests or young were observed beyond or to either side of the current quadrat.

Within each quadrat, nests were recorded as (1) adult on new empty nest; (2) with egg; (3) small chick (still naked); (4) medium chick (all downy); (5) large chick (flight feathers beginning to grow until almost all down gone); (6) prefledging chicks (some down remaining on forehead, neck and flanks, about one to two weeks until fledging); and ( 7 ) as unattended but recently used nest sites (abandoned, failed or fledged). High nests were viewed with a pole-mounted mirror. Within and near the quadrats, 33 adults and 46 chicks were weighed, measured and banded.

\section{Results}

Figure I illustrates the colony area as estimated from aerial photography. The limits of the colony often coincided with clear boundaries between vegetation formations, and showed no discernible change between 1994 and 1997. The present configuration of the protected area was established in 1993 based on Clapp's survey (Clapp 1987), with some allowance for a buffer zone but coinciding with property boundaries where appropriate. Figure $I$ indicates that nesting is now occurring outside the protected area to a small degree.

Within the 54 quadrats surveyed for nests, the sample area was 1.215 ha comprising $7.4 \%$ of a 1994-1997 colony area of 16.52 ha. The mean nest density was 293 active nests per hectare. Total active nest sites were then estimated at 4,839. Approximate $95 \%$ confidence limits for this estimate, based on the observed variance in the number of nests per quadrat, are 3,824 to 5,854. Nest site distribution was aggregated, deviating significantly from a random (Poisson) distribution $\left(\chi^{2}=207, P<0.001\right)$.

Table 1 indicates the frequency of nests at each stage observed in the quadrats. The presence of stages ranging from incubating adults to pre-fledging chicks, but no fledged young, indicates the survey was timed to observe both early and late 
Table 2. Nest sites of Red-footed Boobies $(n=347)$

\begin{tabular}{lrc}
\hline Species & No. & \% Freq. (recorded nests only) \\
\hline Rhizophora mangle & 23 & 10.1 \\
Avicemin germinams & 2 & 0.9 \\
Laguncularia racemosa & 65 & 28.6 \\
Conocarpus erectus & 63 & 27.8 \\
Thespesia populnea & 51 & 22.5 \\
Ficus auren & 4 & 1.8 \\
Guapira discolor & 2 & 0.9 \\
Bursera simariba & 17 & 7.5 \\
Unrecorded & 120 & \\
\hline
\end{tabular}

nesters. No nests were under early construction during the survey, though we have no information as to whether later nesting or re-nesting may have occurred. No dead chicks or adults were found in the quadrats or elsewhere in the colony. We conclude that our nesting population estimate is close to representing the whole breeding population active in Little Cayman in 1997.

Table 2 shows the tree species used for nesting. The high proportion of nests for which the tree species is unrecorded, resulting from difficult field conditions, is probably not unbiased with respect to habitat and so these figures should be interpreted with caution. The three mangrove species (Rhizophora, Avicennia, Laguncularia), and Conocarpus and Thespesia are restricted to the wetland and wetland to dry transition zones respectively, where dense nesting occurs throughout. Ficus and Guapira occur both in transition and dry habitats. Bursera appears to be the major nest tree in the northernmost reaches of the colony's core, where nesting extends into a dry evergreen woodland in which Bursera is dominant. Nesting was also observed in Plumeria obtusa in this zone, though not within the quadrats. To the eastern and western ends of the colony this dry woodland is replaced by an open thicket, lacking tall canopy emergents, in which nests are totally absent.

One transect through the centre of the colony (the third transect from the western end, see Figure 1) passed through a nesting area of Magnificent Frigatebirds Fregata magnificens. The nesting area extended from the pond shore for $60 \mathrm{~m}$ inland at this point: the overall dimensions of the Frigatebird nesting area were not determined. Nest density in the four quadrats averaged $0.2833 \mathrm{~m}^{-2}$. Most nests had hatching eggs, small chicks or medium chicks. We estimate approximately 100-120 Frigatebird nests were present in total.

\section{Discussion}

The stability of the nesting colony boundaries from 1994 to 1997, and the close coincidence between vegetation community boundaries and the nesting limits of the Boobies in some areas, suggests that the colony size and extent may be somewhat constrained by the availability of suitable nesting trees. Although aerial census techniques have been used with some success for large, white birds (Frederick et al. 1996, Rodgers et al. 1995, Kerber 1994), this did not work well for censusing Red-footed Boobies in Little Cayman. Even on the low elevation 
1997 photographs, white morph adults could not be distinguished from large downy young, and brown morph adults are largely invisible. Since brown morphs in this colony account for about $90 \%$ of the adults (Diamond 1980), many nests are obscured beneath vegetation, and a constant proportion of adult birds cannot be assumed to be breeding in each year, there is little basis to expect a systematic correlation between the density of white spots on aerial photographs and the density of active nests. Indeed, no significant correlation, other than the position of the colony boundary, was found when we compared our transect data to the corresponding areas in the 1997 aerial photographs. It is therefore inescapable that effective monitoring of the breeding population size of Boobies in Little Cayman will continue to require area sampling on the ground to estimate the nest density throughout the colony. The costs of this technique are high: in this case, 125 person-hours and US\$3,250 without factoring in values of donated services, housing and food.

Although Clapp (1987) reported a colony area of 9.46 ha, re-analysis of his tabular data indicates an area of 13.3 ha, compared to the 16.5 ha estimated in this study. Comparison of his mapping with this study also indicates some possible confusion in 1986 transect positions toward the eastern end of the colony. Suitable nesting habitat was absent in 1997 in the area where Clapp indicates nesting outside the present colony, and there is no evidence of major vegetation changes over this 11 -year period. Nevertheless the colony has expanded to the north and the west since 1986, in the central and western sectors of the colony. Whether this has been a gradual expansion, or is a short-term fluctuation, is not known. As is indicated in Figure 1, nesting is now occurring outside the protected area and additional land acquisition will be required to bring the full colony under protection with an adequate buffer zone.

Internal inconsistencies in Clapp (1987) complicate comparison of nest site density between the two surveys. Clapp reported collecting data from a $7 \cdot 3-\mathrm{m}$ transect width, but areas and transect lengths quoted in his Table 3 imply a $3.65-\mathrm{m}$ transect width. Clapp (verbally to E. A. Schreiber 1997) now believes the reference to $7.3-\mathrm{m}$ transects is an error in his paper, on which basis we presume the published estimate of 237 nests / ha is correct, compared with 293 nests/ha found in 1997. If we use the revised 1986 colony area estimate of 13.34 ha and a nest site density of 237 nests/ha, we recalculate 3,155 nesting pairs in 1986. We therefore tentatively conclude that in the 11-year period 1986 to 1997, the nesting population of Boobies on Little Cayman increased from c. 3,155 pairs to c. 4,839 pairs. The increase is significant at the $95 \%$ probability level if the various assumptions discussed above are valid, but uncertainty about the true colony area in 1986 remains. Given the unknown annual variation in nesting population size, this increase should not necessarily be interpreted as a simple temporal trend. It may alternatively represent a high point in some shorter-term pattern of variation.

Schreiber et al. (1996), drawing on what little published data are available, estimated the total Caribbean population of Red-footed Boobies to be about 13,750 pairs. On this basis the colony on Little Cayman makes up $30 \%$ of the entire Caribbean population.

Despite protected area status there are concerns for this internationally significant breeding colony's future. There is a recent surge in land development interests in Little Cayman, stimulated in part by government initiatives such as the 
introduction of central electricity generation in 1991 and the completion of a full circumference road in 1992. The human population on Little Cayman has begun to increase: aircraft arrivals increased from 14 per month in 1983, to 400 per month in 1993. If the tourism and residential development pattern on Little Cayman follows the exponential course seen in Grand Cayman over the past 20 years, the Booby Pond Nature Reserve will become an island of natural habitat surrounded by developed land over a similar time frame. Careful buffering of the colony from the effects of neighbouring development will become extremely important.

Little Cayman is currently serviced by a small grass airstrip (Figure 1). Large numbers of Boobies cross the aircraft take-off path when the birds return to the colony at dusk. With increasing activity on the island there are calls for a new or upgraded airport, with various locations to the north of the Booby colony under consideration. Currently bird-strike incidents on Little Cayman have been few and minor, with the relatively slow-moving, propeller-driven aircraft currently in use apparently avoidable by the Boobies. An upgraded airport anywhere in the vicinity of the colony would almost certainly create severe and dangerous bird-strike problems if opened to jet aircraft. Further studies are planned for 1998, to map the major feeding grounds for this colony and to describe the principal Booby flight paths in and out of the colony in order to better assess bird-strike risks to aviation.

\section{Acknowledgments}

This survey was supported in part by the Royal Society for the Protection of Birds, in conjunction with the National Trust for the Cayman Islands, and the Ornithological Council. Mrs Janet Walker kindly provided accommodation for the field crew on Little Cayman, with support also offered by many other residents and businesses on the island. ArcView software used for image analysis was donated to the National Trust by the software developers, ESRI. Digitized and ortho-rectified aerial photographs covering the entire Booby Pond Nature Reserve were made available by the Cayman Islands Government's Land Information System, and the 1997 aerial photography was made by the Cayman Islands Government's Mosquito Research and Control Unit.

\section{References}

Cayman Islands Government (1993) The Animals (Sanctuaries) (Amendment) Regulations, 1993. Cayman Gazette No. 24 of 1993.

Clapp, R. B. (1987) Status of the Red-footed Booby colony on Little Cayman Island. Atoll Res. Bull. 304: 1-15.

Diamond, A. W. (1980) The Red-footed Booby colony on Little Cayman: size, structure and significance. Atoll Res. Bull. 241: 165-170.

Frederick, P. C., Towles, T., Sawicki, R. J. and Bancroft, G. T. (1996) Comparison of aerial and ground techniques for discovery and census of wading bird (Ciconiiformes) nesting colonies. Condor 98: $837-841$.

ICBP Seabird Specialist Group (1984) Priorities for seabird conservation and associated research. Pp. $771-779$ in J. P. Croxall, P. G. H. Evans and R. W. Schreiber eds. Status 
and conservation of the world's seabirds. Cambridge, U.K.: International Council for Bird Preservation (Tech. Publ. No. 2).

Kerber, R. H. (1994) Colonies and numbers of Ross' Geese and Lesser Snow Geese in the Queen Maud Gulf Migratory Bird Sanctuary. Canadian Wildlife Service (Occasional paper No. 81).

Rodgers, Jr., J. A., Linda, S. B. and Nesbitt, S. A. (1995) Comparing aerial estimates with ground counts of nests in Wood Stork colonies. J. Wildl. Manage. 59: 656-666.

Schreiber, E. A., Schreiber, R. W. and Schenk, G. A. (1996) Red-footed Booby (Sula sula). In A. Poole and F. Gill, eds. The Birds of North America. Philadelphia: The Academy of Natural Sciences; Washington, D.C., The American Ornithologists' Union, No. 241.

Steadman, D. W., Pregill, G. K. and Olson, S. L. (1984) Fossil vertebrates from Antigua, Lesser Antilles: evidence for late Holocene human-caused extinctions in the West Indies. Proc. Natl. Acad. Sci. USA 81: 4448-4451.

van Halewyn, R. and Norton, R. L. (1984) The status and conservation of seabirds in the Caribbean. Pp. 169-222 in J. P. Croxall, P. G. H. Evans and R. W. Schreiber, eds. Status and conservation of the world's seabirds. Cambridge, U.K.: International Council for Bird Preservation (Tech. Publ. No. 2).

FREDERIC J. BURTON

National Trust for the Cayman Islands, P. O. Box 31116 SMB, Grand Cayman, Cayman Islands.

PATRICIA E. BRADLEY

P. O. Box 907 GT, Grand Cayman, Cayman Islands.

ELIZABETH A. SCHREIBER

The Ornithological Council, 4109 Komoc Court, Alexandra, VA 22306, U.S.A.

GARY A. SCHENK

4109 Komoc Court, Alexandra, VA 22306, U.S.A.

RICHARD W. BURTON

2 Madeira Park, Tunbridge Wells, Kent TN2 5 SU, U.K. 